ROCZNIK ADMINISTRACJI PUBLICZNEJ 2017 (3)

ARTYKUŁY Nauka administracji / Administrative science

DOI 10.4467/24497800RAP.17.015.7066

http://www.ejournals.eu/RAP/

ISSN 2449-7800 (online), ISSN 2449-7797 (print), p. 255-279

Drahomíra ONdRová ${ }^{1}$

\title{
Challenges of Modern Public Administration and Ethical Decision-Making
}

Each man judges correctly those matters with which he is acquainted; it is of these that he is a competent critic.

Aristotle, The Nicomachean Ethics

\section{Introduction}

The question of ethics is one closely linked to human existence involving character traits, ethical conduct and morals of human beings. Various ethical theories try to define what is good or bad, right or wrong to do, and at the same time evaluate bad and wrong from the point of view of values and criteria which are stated by them as ethical and morally reasonable, required and proper to follow. As, in principle, ethics has to do with actions of man, it requires adjustments in one's actions, attitudes, especially in the case of public administration, its management activities, ethical climate in organisations and the administrator's ethical competences in decision-making processes. Their strong and weak abilities evident in a wide range of their interrelations, e. g. relations among colleagues, subordinates and superiors, are at the same time reflected in their contacts with the citizenry and general public. Moreover, attention should be drawn to how the most basic principles of democracy closely interrelated with public participation in governing the public affairs are applied in public administration.

The executives' behaviour, their activities and decision-making based on ethics are necessary and essential for any effective and stable political and administrative authority and for the strengthening of democratic, social and economic structures It is then evident that ethical public administration is not only wanted or a kind of wishful desire but a necessity as nowadays we are frequently confronted with misdemeanours, small or big cases and scandals of officials in either high or small posts proving that corruption can disturb not only the whole society's economic stability but endanger

1 Doc. PhDr. Drahomíra Ondrová, CSc., Department of Public Policy and Theory of Public Administration, Faculty of Public Administration, Pavol Jozef Šafárik University in Košice, Popradská 66, 04132 Košice, Slovak Republic. 
free trade on which the free market economy is based, and thus jeopardise the basic ideas and principles of democracy which have to be protected and defended. Therefore, such aspects as democratic pluralism, ethical decision making, citizen's participation in governance, quality of life, legitimacy of public institutions and the management style of the public sector must be based on and derived from moral and ethical foundations. As expressed by Denhardt, "Ethics should be thought of as helping to frame relevant questions about what government ought to be doing and how public administration ought to go about achieving those purposes"2.

\section{Traditional and modern public administration}

Good public governance means that besides the achieved outcomes, the methods and ways in which they have been reached are emphasised, so "the ends do not justify the means". Bovaird and Löffer underline that the processes by which different stakeholders interact have also a major importance in themselves, thereby the processes matter emphasising the role of citizens as well ${ }^{3}$. Further, as emphasised in the White Paper on European Governance, the concern must be shifted to the ways in which public governance uses their powers given by citizens $s^{4}$. This aspect has to be taken into consideration when dealing with the new public good governance in comparison to traditional public administration, which treated citizens as subjects, where leaders and administrators had practically absolute power and control over people. Eran Vigoda from the Haifa University argues that "the old orthodox public administration controlled and monitored many, if not all, aspects of citizen's daily lives, creating a pattern of coerciveness in the citizen-ruler relationship" ${ }^{5}$. In the former Eastern-Bloc countries during the time of totalitarian regime, citizens had to more or less accept the unlimited tyranny enforced by the state where the voices of the public were hardly heard in such an unreceptive environment as it is called by Eran Vigoda. Charles Garofalo characterises traditional public administration in the following way: "Traditional public administration mostly proceeds from political inputs, with services monitored by the bureaucracy. Public administrators are compliance-oriented and risk-averse officials whose commitment to the public interest and citizen participation is tenuous at best. Monopoly of

2 K. Denhardt [in:] A. Hondeghem, Ethics and accountability in a context of governance and new public management, Amsterdam: IOS Press 2009, p. 29.

3 T. Bovaird, T. Loffler, Public Management and Governance, New York: Routledge 2009.

4 European Governance: A White Paper, Commission of the European Communities, $\operatorname{COM}(2001)$, p. 35.

5 E. Vigoda, From Responsiveness to Collaboration: Governance, Citizens, and the Next Generation of public Administration, "Public Administration Review" 2002, September/October, Vol. 62, No. 5, p. 532. 
public service, rules, hierarchy, and stability characterize the environment of traditional public administration"6. However, as Laura Jensen and Sheila S. Kennedy observe, "substituting new forms of collaboration and management for hierarchical, bureaucratic chains of command cannot and should not mean abandoning traditional commitments to the public values incorporated in public law, such as liberty, equality and fairness"7.

Good governance values, which are emphasised by the European Union's official papers, including democracy, lawful state, effectiveness, usefulness and credibility, represent a classical example of public sector values enhancing cross-sector partnership. Those are the values from whose principles, rules and guidelines regarding proper behaviour in the public sector might be derived. Therefore, public sector values should have supremacy over the principles of public sector officials' actions together with the implementation of the so called zero-gift policy according to which a public official may receive absolutely nothing or excluding any participation in various social graces. Confidence in public administration is eroded when it appears that public servant's actions are influenced by a gift of any sort, a revelation that personal gains of some form of benefits which might influence the public official's decisions on some matters considerably fuel people's distrust in the elected political representation and civil servants.

\subsection{Modern ethical public administration}

\subsubsection{Ethical public administrative management}

Nowadays, ethics in public administration presents a widely discussed challenging problem area not only from the theoretical point of view but the aspect of the validity of ethical and moral principles and norms in the field of public administration practice. Consequently it is in the interest of the whole society how services for citizens are provided and made available given not only economic but also ethical means, as they finally impact the citizenry. For that reason, the importance of articulating ethics and ethical values that define and underpin the public service cannot be underestimated. Effective public administrative management necessarily needs to have an ethical orientation, if it is to be beneficial for an organization in the long term; the constantly cultivated ethical context is a guarantee of professional success and survival. The ability to control and influence others creates the basis for the execution of power in the management of public administrative

6 C. Garofalo, Governance and Values in Contemporary Public Service [in:] Value and Virtue in public Administration, a Comparative Perspective, M.S. De Vries, P. Kim (eds.), United Kingdom: Palgrave MacMillan 2014, p. 19.

7 L.S. Jensen, S.S. Kennedy, Public Ethics, Legal Accountability, and the New Governance [in:] Ethics in Public Management, H.G Frederickson, R.K. Ghere (eds.), New York: M.E. Sharp, Inc. 2005, p. 221. 
organisations when public goals should be attained, then it is necessary to transform all individual interests into coordinating activities, finally issued in the effective accomplishment of community public interests as 'leaders' effectiveness is rooted in the awareness that power and vested interests permeate all aspects of their organizations and the interactions of people within them"s.

A regards the management of society, the absence of competent and responsible political leaders, and we could add mature ethical leaders, gradually opens up a space for superfluous and excessive bureaucratic practices, quite often motivated by personal intentions "to live from politics" and "not to live for politics". A strong leader with adequate charisma and respect for political and public ethics represents one of the promising ways of how to do away with conflict-like fragmentary societal interests with the capacity to mobilise people in order to work for society's common good, and in this way to stimulate the overall acceleration of political and public life. An inseparable part of effective and, importantly, ethical management is determined by ethical decision-making processes which may be defined as a conscious and reasonable decision in compliance with professional ethics.

Additionally, ethical public management includes several prerequisites which have to be taken into consideration and applied:

The first one is to reconsider a direct implementation of private sector rules administrated mostly by New Public Management and its direct transformation and functioning of the public sector.

Critics of New Public Management, e.g. Maesschalck, Cooper, Denhart and Frederickson, stress that the direct principles and norms of the functioning of the private sector have to be carefully evaluated before transposing them straight to the public sector since the rules of good governance besides economic factors must include the following areas: public interests, mutual cooperation with the public, ethical values and principles. More specifically, the pro-market NPM model underpins the market-centred standards based on market-driven management such as competition, cost-effectiveness, economy and profitability, which, of course, have to be taken into consideration but it is more that doubtful to marginalise the traditional ethical values and standards, such as trustworthiness, reliability, personal integrity, accountability and fairness.

According to some authors ${ }^{9}$, the popularisation of the NPM model is a kind of continuation of the newly emerging utilitarian and neoliberal ethics prioritising market principles in public decisions, business-style

8 C.L. Jurkiewicz, Power and Ethics: The Communal language of Effective Leadership [in:] Ethics in Public Management. Collection of papers, New York: M.E. Sharpe, Inc. 2005, p. 97.

9 M.S. Haque, Contemporary Trends and Dilemmas of Administrative Ethics in the Developing World [in:] Value and Virtue in public Administration..., p. 181. 
management in public administration strategically being oriented towards new economic policies such as privatisation, deregulation and liberalisation emphasising the value of the public-private partnership between local public administration and the private sector. Based on the real indications, it is evident that a closer partnership and cooperation of the public sector with private often leads to the destruction of the former's neutrality and the administrator's integrity as it might create "a greater avenue for all sorts of corruption when making business-deals with private businesses (...) and what's more it leads to the destruction of the public service ethos (...) and public sector's unique identity" 10 . The scope of the presence of this phenomenon s evident in Slovakia in many areas, e. g. in the healthcare and justice systems, non-transparent public procurement covering all spheres of life, dealing with EU funds, etc., fundamental ethical and human values which must become a part of public service, such as justice, equality, human dignity, pursuing community preservation and predominance of public interest are given up in favour of individualist self-interests, consumer society standards, unfair competition and profits. It appears to be the dawn of Aldous Huxley's Brave New World, the world where only those who are young and successful are worth of being alive.

\subsubsection{Promoting public interest}

Promoting public interest by public administrative bodies is considerably different when compared with private companies and their management. Private companies are of the opinion that they best serve general interests by closely following their own economic interests. Their tasks are to be highly efficient uncompromisingly and diehard competitive in the marketplace, the profit is understood to be not only their main goal but it is viewed as the most positive social and economic good without taking into consideration some negative consequences which might occur, e.g. environmental, damage to the physical or mental health of their employees, exploitation of the workforce, corruption practices, etc. Therefore, it is not only necessary that the government should draft $t$ some regulations but to implement ethical public sector values, principles and norms which have to be reinforced in public administration together with moderating and in many cases abandoning the New Public Management philosophy as an ideal one for the public sector. The concern in the public sector has to be shifted to responsiveness to citizens, the term which has to be used instead of calling them clients; also needed is a shift towards the new thinking of understanding public sector governance as a place of the citizens' effective participation in public affairs and collaboration among them.

Even if public interest is not properly defined, generally it is understood as the opposite of following one's personal or bureaucratic organisation interests instead of public, citizens' and the entire community's interests.

10 Ibid., p. 184. 
Although there is not an exact definition of public interest, it does not mean that public administrators and representatives should not consider it as a general guide in fulfilling their obligations and duties, otherwise there can be no guarantee that democratic principles would prevail in our society, principles which would impede the abuse of power in the public sector, tackle conflict-of-interest practices, corruption, and above all prevent the misuse of political dominance in public administration. Confidence of citizens towards the pursuing public interests is above securing one's own personal privileges or group benefits. The implementation of ethical and moral principles might help not only to cherish our contemporary delicate and vulnerable democratic society but to make it healthier, more stable and stronger. Reducing political dominance in public administration, avoiding its direct management by politicians and the preference of political neutrality of administrators might create a more future-oriented and beneficial governance in public administration. Besides that, political domination in public administration is substantially influenced by the frequently changing political conditions caused by repeated reshuffles of governments in Slovakia where they often leads to replacing professionally competent and ethically mature public administrative bureaucrats. Such practices are in stark contradiction to developed democracy. It goes without saying that one of the preconditions of effective and highly-performing public administration is the top professional level of its executives and administrators whose main mission is not only to provide services to the state and general public but offer partnership and collaboration with citizens. As regards the quality of services, which is constantly improving, it is likewise necessary to constantly cultivate the administrators' professionalism and at the same time to improve their relationship with citizens which is one of the premises of the Cultural Revolution going on in public administration proclaimed by statements of many scholars and experts, e.g. Thompson and Frederickson.

As regards both levels of public administration, the state and local one, the most fundamental goal of public administrative ethics is to provide a precise and accurate operation of public administration by means of the protection and support of public confidence towards professionalism and transparent activities of its officials. In order to reach these goals, it is necessary to motivate public administrators to act in accordance with law, public interest and ethics. As to the decision-making processes in public administration, it means to act politically neutrally, independently and open-mindedly while taking into consideration the needs and demands of the citizenry. Public administrators are expected to serve their citizens and to be accountable to them. In a state operating transparently, the government follows its main goal which consists predominantly in cooperation with civil society as an inseparable part of state structures, procedures and 
institutions motivated by efforts to find out innovative non-governmental solutions concerning collective problems which are consistent with the citizenry's expectations of transparent solutions. This is the only way to win citizens' confidence for values of legitimate state authority.

\subsubsection{Active participation in governance}

Encouraging democracy means to encourage pluralism, participatory structures and processes within public administration combined with a greater diversity of perspectives and interests. David Rosenbloom has expressed this using the following words: "a society representative public service is likely to be more diversified, in terms of values and political perspectives than a homogeneous one"11. Further, he points to the fact that allowing public participation gives an opportunity for public administrators and representatives to be in closer contact with the citizenry and thus better recognise their views and needs. According to Rosenbloom, the pluralist approach requires at least two factors as regards public administration organisation:

1. Organisational missions have to be of a compound character rather than unified.

2. At governmental level, it requires the voice and representation of constituencies.

Pluralism is closely linked to decentralisation processes and establishing local and regional administrative centres which are closer to citizens and in many aspects able to better satisfy their needs and improve the quality of their lives. But on the other hand, it requires better coordination of those processes and control of administrative units, to fill in this way the vacuum regarding the state-citizen relationship while at the same time to strengthen trust in public institutions.

Participation of citizens in public administration has to be a long-term coproduction process based on local public control, activities provided by interests groups and recently the need has been emphasised of participation by means of member representation on governing boards, committees and community action programmes. Active public participation helps to build the needed community identity and a sense of open communication with local and state authorities and thus foster a different model of administrative service delivery having joint-venture characteristics where the citizen is an active participant, not merely a consumer or subject. Consequently, citizens are jointly responsible for providing services and the quality of community life and in this way the resident's loyalty to the place where they live and to their neighbours is built. Loyalty and devotion to locality result from the "face-to-face contact and an investment of energy in the improvement

11 D.H. Rosenbloom, Public Administration, Understanding Management, Politics, and Law in the Public Sector, New York: Random House 1986, p. 476. 
of localities and communities"12 or as it is proclaimed in the European Ombudsman's mission statement "building trust through dialogue between citizens"13.

\subsubsection{Contact client-centred administration}

Treating citizens as individuals rather than anonymously as abstract cases is the idea which is helped by establishing the so called client-centres in Slovakia. They must be flexibly structured around the clients' needs and demands, they must be more or less defined by the citizens' requirements rather than by the needs of administrative organisations and institutions; furthermore, they are aimed at reducing the need to complete an enormous pile of forms, considerably reducing administrative paperwork, enhancing the effectiveness of official procedures and in general to minimise the burden of bureaucratic practices. At the same time, they are closely connected with the building of effective communicative channels which would enable the provision of an active dialogue with citizens. Citizens must feel that their city or municipality listens to what they talk about, that it is interested in their ordinary problems and needs, and what is more, willing to find solutions to their problems. Therefore, municipalities and local governments should initiate the creation of their concepts of communication with citizens and present their intentions in such a way as to make them understandable and transparent for all participants of the decision-making processes applied. For that reason, the most important is the sense for the "petty problems" as for people really small decisions are the most tangible ones which considerably influence their everyday lives.

As Džatková points out, "active public participation is closely interrelated with the surplus ethical value based on the presumption of highlighting the range of transparency and ethicality of public administration. Moreover it safeguards the reliability of control mechanisms, answerability, validity and legitimacy of decision-making processes" 14 .

\subsection{Professionalism, virtue ethics, deontological normative principles} and norms of the consequential ethics

\subsubsection{Virtue ethics and character traits in public administration}

Articulating virtue ethics in public administration is closely connected with the professional ethical traits of administrators requiring the advocacy

12 D.H. Rosenbloom, Public Administration..., p. 412.

13 P.N. Diamandouros, European Ombudsman speech on Open dialogue between institutions and citizens - the way forward, www.ombudsman.europa.eu/en/activities/.../en/.../html, Bookmark cit. 14 March 2012.

14 V. Džatková, E-participation in the public administration modernization processes [in:] Actual Challenges and Problems of Public Administration II, Košice: Faculty of Public Administration UPJŠ in Kosice 2015, p. 159. 
and setting-up of administrators' ethical behaviour and decision-making relating to both leaders and rank-and-file administrators. Emphasising the inherent professional virtues and moral qualities of public servants, such as honesty, sincerity, integrity, compassion, dedication, competence, truthfulness, trustworthiness, courage, faithfulness, collegiality, loyalty, optimism, and selflessness accompanied by one's own accountability for his/her conduct, acts and decision-making is settled in European Council documents, e. g. the European Code of Good Governance elaborated by the European Public Defender of Rights and issued by the European Parliament in 2001.

\subsubsection{Implementation of the deontological normative principles} and norms

This is seen as a critical state of affairs to provide a common frame of the deontological normative reference of all principles, norms and standards which would be applicable in public administration service, including public officials and the public as well. Still, in spite of many obstacles, the necessity to create a relatively fixed normative list or code of conduct of universal ethical professional values, principles and norms denoting what is right and what is wrong to do appears to be inevitable. According to the proposals scattered across different documents, it should include such universal ethical qualities as responsibility and responsiveness to civil society, fairness, impartiality, equality, legality, neutrality, reliability, and transparency aiming at observing public interest. The normative principles and norms should serve as a guide for public officials and help them develop not only the appreciation of ethical issues but at the same time initiate them to imply the created deontological mechanism in public service delivery in order to make public administration more operative, efficient and reactive.

At the same time, it means supporting and monitoring the ethical conduct and the decision-making processes provided by public administration institutions and organisations. From the literature of the subject it is evident that the specific criteria derived from the body of knowledge regarding the general normative guidelines relevant to public service delivery suggest that a kind of universally acceptable code of conduct seems to be a necessity for public officials, if they are to perform their activities ethically.

\subsubsection{Consequential ethics and public administration}

Consequential ethics judges actions from the perspective of its outcomes and consequences including productivity, efficiency, economy, effectiveness, competitiveness, and performance, benefits for the community and generally the quality and satisfaction of citizens. As regards both levels, the state and local one, the most fundamental goal of public administrative ethics is to ensure precise and accurate operation of public administration by means of the protection and support of public confidence in the public executive 
officials and administrators. In order to reach these goals, it is necessary to motivate public administrators to act in accordance with law, public interest and ethics, so as regards - decision-making processes it is desired to act politically neutrally, independently and open-mindedly taking into consideration impacts on the needs and demands of the citizenry. Public administrators are expected to serve their citizens and be accountable to them for all impacts on their lives and accordingly to exclude all negative influences or at least to minimise them.

\section{The ethical decision-making process}

In general, under the decision-making process we understand the selection from several reasonable options or preferences. The ethical decisionmaking process, in turn, is usually characterised as the course of the action of choosing from alternatives which are based on public administrative values, moral responsibility and personal accountability of public administrators towards the citizenry, colleagues at work, and at the same time towards each other, and last but not least towards a certain community and society. Finally, their decisions have to reflect their respect for professional values, principles and norms.

First of all it is necessary to mention the ethical project of the decisionmaking process elaborated by the Council of Europe in 2009. Its main aim is to help public servants in making their decisions observing the following steps in order to respect both the objectivity and ethical nature of their decisions.

The first step consists in the exact definition of the problem which has to be resolved. Within this step, it is important to examine the specific context where the problem occurs. A bureaucrat should answer the following questions: Which are the main factors influencing my decision? At what time must the decision be taken and when are its consequences evident? Who is to bear these consequences ${ }^{15}$ ?

In this context, Törbjörn Tännsjö offers the Applied Ethics Model suggesting to follow moral judgment processes that can contribute to the final ethical conduct consisting, first of all, of the pursuing true or reasonable moral principles to be applied to a specific case, and then bringing together all the relevant facts of the situation which finally might bring us to a practical conclusion.

15 Council of Europe, The Ethical Leadership Program: A Facilitator's Guide, Council of Europe 2009, Project No. EC/1062 (cit. 8 April 2016), http://www.coe.int/t/ DGHL/cooperation/economic crime/corruption/projects/TYEC/1062-TYEC Facilitators\%20Guide.pdf. 
Figure 1. Applied Ethics Model

1. Moral principle

2. Account of the relevant facts

3. Practical conclusion

Source: Model of Applied Ethics (T. Tännsjö, 2008, p. 4), modified by the author.

In the second step, it is necessary to identify and take into consideration all participating parties. This involves making a list of all possible participants to find out their point of view on the problem in question. It means that the attention has to be given to obligation identification, e.g. towards the community, the parties affected by our decisions and the people involved. The main aim of this second step consists in avoiding sudden and immediate decisions, especially when solving serious problems influencing a number of people or a whole community. Therefore, it is necessary to have in mind all ethical and moral issues based on the deontological or principle-based ethical theory and virtue ethics which suggest focus on the community standards.

The third step concentrates on the basic principles of laws, regulations and public policies. The Council of Europe advises making a list of standards, principles and norms which might be the most relevant for the solution of a particular problem and to specify potential procedures which have to be followed. Moreover, it is necessary to find out if there is a potential for any legal consequences as regards the decision made, or if it is needed to find out any legal support and assistance. Besides that, the identification of the relevant organisational modus operandi is needed.

The fourth step concentrates on the identification of consequence, therefore a consequentialist approach is implemented here which accounts for all ethical problems in terms of harm or benefits for individuals as well as a community. After providing a necessary evaluation of the previously applied decisions, if needed, an alternative decision has to be made. All alternatives have to be carefully judged in order to determine all impacts for every participating party. Also, the legal and procedural consequences including impacts on ethical values, norms and principles have to be judged and only after that must the most reliable alternative be chosen. This step, which is derived from the consequentialist approaches, consists in the identification and evaluation of all impacts on citizens and community. In this context, the application of the approaches of social consequences ethics might be the most relevant together with the model of Thomas Jones. Apart from the significant role which is played by all probable consequences in a specific decision-making process, Thomas Jones's model emphasises the important role of social consensus, probability of effect, temporal immediacy, proximity, and the concentration effect. According to him, all of 
the mentioned factors are considered to be components of moral awareness intensification significantly influencing decision-making processes.

The fifth step embraces endeavours to discover diverse opinions. If an administrator is not quite sure what to do or if his/her decision might have a major weight, then it is useful to obtain a judgment made by an independent and reliable actor. Making use of trustworthy mechanisms by means of which he/she tries to find out a formal advice-giver within the public sector might be very helpful. Another way to come to the most proper solution of a dilemma is to discuss the case with colleagues who might help an administrator to see the matter in question from a different angle. In terms of public administration decision-making processes, it is practical to apply Lawrence Kohlberg's "role taking method" based on moral contemplation and ability to perceive a situation from different viewing platforms.

The sixth step includes choosing the final decision and action. At this stage, an administrator tests his/her final decision contemplating what a definite decision will look like, for instance on the first page of a newspaper, or how he/she will look at the decision after one year or several years. The following questions might help to come to the most correct decisions: Will I feel OK, will I be proud or feeling guilty when explaining my decision before my family? Will I accept my decision even in case I am influenced by it ${ }^{16}$ ?

The final stage might seem to be extended if not pretentious, but on the other hand it enables the decision-maker to perceive and look at his/her decision from different angles and from a new perspective. At this stage, the administrator's creativity plays the most essential role. Additionally, public administration staff cannot afford to be pressed by interests of certain groups, individuals or bound by some measures which are applicable in similar cases; it is always better to follow an action which is somehow different or unusual but in a specific case indicates a more accurate and correct equivalent.

This type of decision-making procedure included in six steps and elaborated by the Council of Europe significantly resembles the eight linear steps of making decisions presented by Linda Treviño and Katherine A. Nelson. Just like them, the Council of Europe suggests in its first step of the ethical decision-making process to gather all necessary data and facts regarding the decision-related problem and eventually to scrutinise the specific context influencing the decision. The second step identified by the European Council pointing at the identification of all participants is elaborated in detail in the third step by the aforementioned authors. Both compared decision-making procedures put emphasis not only on the simple identification of the participants in question but on the endeavour to see and understand

16 Council of Europe, The Ethical Leadership Program... 
the actual situation from different angles and perspectives. Furthermore, parallels between both mentioned concepts can be seen when the administrator chooses the final decision and by means of questions verifies whether his/her decisions are in compliance with ethical requirements and honesty to the public.

According to the Council of Europe, it goes without saying that ethical acting and decision-making are inseparable parts of the practical activities and services performed in public administrative management. In the European Council project, the idea expressed by the United Nations International Code of Public Administrators Conduct finds its practical application. It is expected that public servants will act entirely respecting public interest having in mind benefits for the community and its welfare. Moreover, their obligation is to ensure and even strengthen public confidence in the integrity of public administration ${ }^{17}$.

\section{Models of ethical decision-making}

As regards the significance and difficulty of taking decisions in public administration in comparison to the conventional area of the usual decisionmaking, administrators must decide not only taking into consideration different probable alternatives but consider the ethical consequences of the decisions they make. Therefore, the administrators and executive officials must refrain from pronouncing their decisions spontaneously as this might bear the sign of one's personal attitudes and sentiment quite often marked by the non-objective evaluation of a specific situation or case influenced by one's social background, negative personal character traits, or simply caused by lack of professional qualification and experience. In such sometimes not so easy circumstances in which administrators and executive officials might find themselves, the use of established ethical models trying to find out and define the most proper and reliable ethical and professional procedures regarding ethical acting and decision-making might appear a helpful and supportive device. The purpose of the presented models is to serve as a guide, assistance in order to minimise wrong problem-clarification and faulty decision-making. Also, they might help to avoid unreasonable emotionality and on the other hand to use rational judgment and wisdom when deciding.

\subsection{Linda Treviño's personal and situation interactionist model}

Treviño's model is focused on both variable components, the role of individuals and the organisational environment, if ethical conduct and decisions are to be understood and maintained. Treviño observes that some

17 Council of Europe, The Ethical Leadership Program... 
previous approaches dealing with the ethical decision-making regarding organisations have the tendency to put into the fore either characteristics of individuals or the variable situational components. Neither of them is able to capture the important interface between the two variable components: the role of individuals and the situational contexts ${ }^{18}$.

All those steps are influenced by two types of factors mentioned above: characteristics of individuals and organisations. Among the three characteristics of individual factors, Treviño includes the strength of one's own ego, a field of dependence and the self-control mechanism. Even when people know what the right thing is, they often find it difficult to do it because of group or organisational pressures they meet with, which is quite often determined and influenced by certain administrative management in the organisation. Without the support of public administration management, ethical initiatives would be simply hopeless.

Figure 2. Treviño's Person - Situation Interactionist Model

Characteristics of Individuals

- Individual Differences

- Cognitive Biases

$\downarrow$

\begin{tabular}{|c|c|c|}
\hline \multicolumn{3}{|c|}{ Individual Ethical Decision Making \& Behavioun } \\
\hline $\begin{array}{l}\text { Moral } \rightarrow \\
\text { awareness }\end{array}$ & $\begin{array}{l}\text { Moral } \rightarrow \\
\text { judgment }\end{array}$ & $\begin{array}{l}\text { Ethical } \\
\text { behaviour }\end{array}$ \\
\hline
\end{tabular}

$\uparrow$

Characteristics of Organisations

- Group \& Organisational Pressures

- Organizational Culture

Source: The ethical Decision Making Process (Treviño, 2010, p. 15), modified by the author.

Furthermore, the core of the aforementioned model is based on the Kohlberg model of cognitive moral development. In addition to the stated factors mentioned above, the Kohlberg model offers a definition, measurement tools and overall theoretical basis as a guide for further research in the field of ethics, including public administration ethics.

According to Kohlberg, an individual reaction to a certain dilemma is determined by the achieved stage of moral cognitive development, which further determines one's decision-making process aimed at resolving what is right to do or what is wrong to do in a certain situation. However, the knowledge abilities of an individual cannot sufficiently explain or

18 L. Treviño, Ethical Decision Making in Organizations: A Person-Situation Interactionist Model, "Academy of Management Review" No. 1, p. 601. 
presume the decision-making actions. Therefore, an interactive merger of the cognitive component with the individual and situational variable components are necessary to be taken into account in order to determine more precisely an individual reaction in relation to an ethical dilemma. Moreover, situational characteristics are influenced by a specific authentic work-context and broader organisational culture. The normative culture of the organisation, staff obedience and respect for authority, personal responsibility and accountability for the consequences together with other pressures exerted on administrators all play an important role.

At last, the character of the work provided stipulated by a moral and ethical organisational structure might substantially influence individual moral development ${ }^{19}$.

\subsection{Clarkson's model}

The Clarkson model of decision-making expands Treviño's model by adding to it the role of the so-called subjective nature of the selective perceptual filter covering individual filtering made by an individual decision-maker influenced by his/her perceptual orientation caused by individual differences in perception and thus having an impact on the decision outcomes.

Moreover, Clarkson adds to Treviño's model the pressure of the environmental influences existing outside the organisation which have a considerable impact on the decision-making processes, such as the general work environment of a certain society, character of the government and the legal, social, professional and individual personal environment. As a result, an individual decision-making process has features of environmental factors and individual attributes functioning as a selective perceptual filter.

\subsection{Lawrence Kohlberg's model of cognitive moral development}

Lawrence Kohlberg's moral reasoning theory is known as a cognitive developmental theory which basically focuses on people's psychological approach to decision-making and types of reasoning processes used to arrive at specific moral decisions. Kohlberg defines the structure of the morality concept and its developmental change from childhood to adulthood. Based on his research, he has come to conclusions setting up three basic levels, or stages: preconvention stage, conventional and postconventional or principled-base stage. Each of these stages is composed of two phases.

The preconvention level is marked by two poles that are obedience and punishment; personal awareness or contemplation are excluded. In both stages the individual is mostly influenced by external values, principles and

19 L. Treviño, Ethical Decision Making in Organizations..., p. 601-617. 
norms having direct tangible consequences for his/her actions. Therefore, the individual tries predominantly to follow one's own interests and awards or seek approval.

The second level, called conventional, is based on agreed stereotypes and conventions, such as obedience to authority, fulfilling one's duties, respecting law and obligations or valuing and maintaining norms of good behaviour which are given and approved by the external societal environment. Unconventional decisions may be sanctioned as long as they appear reasonable in the light of the higher principle.

The post-conventional level is based on moral purposes, principles and ideals, upholding social rights and order, supporting consensus and social cooperation. The fourth stage is characterised by the individual's capability to accept wider perspectives of society.

Through the fifth and sixth stages, the right decision is determined by respecting universal human and ethical values and norms. At these stages, the individual possesses capacities to see and comprehend realities behind the stated norms, laws and rules established by official authorities and bodies in power. The moral Stage Five principles serve not only to meet the interest of individuals but also that of society. From the developmentalstage perspective, the principles coordinate the rights and duties of the individual with those of society. The methods of decision-making are due processes ranging from lotteries to voting with a preference for joint decision-making.

Kohlberg's model, which has been found out and tested during the last 20 years, emphasises the cognitive aspect of reasoning when deciding on moral and ethical decision-making issues. Moreover, it serves as a useful key and tool to bring about progress in investigating the cognitive phenomenon of ethical decision-making processes. Kohlberg has shown that in the course of moral development, reasoning about justice increases in complexity and becomes more inclusive.

The limits of the Kohlberg model lies in the fact that tests of moral reasoning are concerned only with the cognition how an individual contemplates moral dilemmas without paying attention to their conduct, what they would do in specific situations when forced to decide. The relation between amoral judgment and a moral act is not clearly defined. A moral judgment is an indispensable precondition but not sufficient for moral conduct, such as honesty, altruism or resistance against temptation. 
Figure 3. Lawrence Kohlberg's Model

\begin{tabular}{|c|c|}
\hline LEVELS & What is considered to be right \\
\hline \multicolumn{2}{|c|}{ 1. level - PRE-CONVENTION } \\
\hline $\begin{array}{l}\text { Second stage - Getting what you want by } \\
\text { trade-off }\end{array}$ & $\begin{array}{l}\text { 1. Right and wrong determined by } \\
\text { reward and punishment Obedience is } \\
\text { a matter of one's interest. } \\
\text { Whatever leads to punishment is wrong. } \\
\text { The right way to behave is that which is } \\
\text { rewarded. } \\
\text { 2. Following rules only when it is within } \\
\text { someone's immediate interest }\end{array}$ \\
\hline \multicolumn{2}{|c|}{ 2. level - CONVENTIONAL } \\
\hline \multirow[t]{2}{*}{$\begin{array}{l}\text { Third stage - Conventional morality } \\
\text { - Performing right roles, interpersonal } \\
\text { mutual congruence of mutual } \\
\text { expectations, views of others matter, } \\
\text { avoidance of blame, seeking approval } \\
\text { Fourth stage- Social contracts and } \\
\text { maintenance of the system }\end{array}$} & $\begin{array}{l}\text { 1. Stereotypical good behaviour, living } \\
\text { in accordance with expectations, which } \\
\text { corresponds to the generally expected } \\
\text { "good behaviour" } \\
\text { 2. Obedience to authority, fulfilling one's } \\
\text { own duties. }\end{array}$ \\
\hline & $\begin{array}{l}\text { Fulfilling duties and obligations which } \\
\text { were agreed on. Upholding laws with the } \\
\text { only exception of some extreme cases } \\
\text { which contradict given obligations. }\end{array}$ \\
\hline \multicolumn{2}{|c|}{ 3. level - POST-CONVENTIONAL MORALITY } \\
\hline $\begin{array}{l}\text { Fifth Stage - Sense of democracy and } \\
\text { relativity of rules, shared standards, } \\
\text { rights and duties }\end{array}$ & $\begin{array}{l}\text { Upholding rules stated by the social } \\
\text { contract. Keeping values and rights } \\
\text { without taking into consideration the } \\
\text { majority opinion. }\end{array}$ \\
\hline $\begin{array}{l}\text { Sixth stage - Universal ethical principles, } \\
\text { self-selection of universal principles }\end{array}$ & $\begin{array}{l}\text { Individual principle of consciousness and } \\
\text { following ethical principles. If laws break } \\
\text { those principles, then act in accordance } \\
\text { with the ethical norms. }\end{array}$ \\
\hline
\end{tabular}

Source: Treviño 1986, p. 605, modified by the author.

\subsection{Bureaucratic model of -making}

In addition to emphasising the important aspects of decision-making processes, the bureaucratic decision-making model pioneered by Graham Allison emphasises the fact that decisions are determined by mutual negotiations among public administrators and administrative bodies while either subject follows its own interests. Such an approach to dealing with problems rejects the idea of the dominant role of the state as a monolith amalgamated colossus unified only by one single interest, but on the other 
hand it indicates that final decisions result from the arena of competition where the ratio of benefits is constantly changeable. At the same time determined by experience and practice, the bureaucratic model reflects administrators' force to imply decisions which are made in their position. As Heywood says, this type of model highlights the "impact on decisions of the organisation values, assumptions and their regular patterns of behaviour rather than a rational analysis and objective evaluation corresponding to the aphorism "where you stand depends on where you sit"20. According to these ideas, public administrators take decisions taking into consideration their own posts and interests as well as pressure of the organisation where they work. The bureaucratic model excludes the role of personal character, individual interests and sympathy, one's personal ethical qualities and moral virtues are left out, too. Therefore, when applying this type of decisionmaking model, it is difficult to speak about the role of ethical leadership and ethical environment in a public organisation when only the position of administrators and organisational interests are counted on. Moreover, this model does not pay any attention to external influences or the cultural and ideological context.

\subsection{Behavioural model of decision-making}

Bommer, Gratto, Gravander and Tuttle are the authors of the behavioural model of ethical decision-making which combines several factors influencing ethical or unethical behaviour reflected within the structure of the decision-making processes. The model presents various categories influenced by such aspects as social, governmental, legal, operational, professional, human resources and, last but not least, one's individual attributes and character traits. All those factors create a context within which decisions are made and implemented. According to this model, the social environment with which an administrator is identified can be defined as a cluster of religious, cultural, and societal values of individual sub-groups which exist within society as an entire whole. Laws, legal provisions, court system and norms creating the entire legal environment together with community norms, customs and tradition having a formal authority are considered to be relevant influential factors as well.

The professional environment is defined as an institutionalised professional context where an administrator provides his/her practical activities. Institutionalisation covers, for instance the existence of professional groupings, implemented procedures and codes of conduct ${ }^{21}$.

The adoption of a code of conduct should not be a goal but an instrument to achieve the objectives supported by ethical management. The code of

20 A. Heywood, Global politics 2, UK: Palgrave Macmillan 2014, p. 136.

21 M. Bommer et al., A behavioural model of ethical and unethical decision-making, "Journal of Business Ethics" 1987, Vol. 6, No. 4, p. 265-280. 
conduct is a right step, which must be followed by some other actions. These should lead to the development of appropriate professional virtues of governmental employees and the overall ethical culture with emphasis on the fulfilment of the obligations and pursuance of public interest $\mathrm{t}^{22}$.

The working environment embodies its culture reflecting administrators' values, opinions, behaviour, management style, and ways of solving problems. Moreover, the working environment considerably influences administrative behaviour, and management decision-making.

The personal environment consists of the family and age groups that influence individuals' moral development. It is generally accepted that the family and friends are one of the most decisive factors influencing moral thinking.

Summing up, we can generally say that the behavioural model is not prescriptive as it adds something more than a descriptive disposition, evident in its attempts to identify reasons causing ethical or unethical conduct reflected in decision-making processes. This model might be primarily inspiring in public administration practice, especially for those who try to develop and then further to implement ethical programmes. Their implementation might be helpful for decision-makers and to a great extent make them come to the most precise decisions more easily. Additionally, the authors of that model focus on the identification of the real factors which are evident in the ethical or unethical conduct before scrutinising human attitudes.

\subsection{The Ferrell and Gresham model}

The Ferrell and Gresham model known as the model of probable dependability is recommended for use as the starting point for the execution of ethical decisions in organisational executive circumstances. This model demonstrates that it is necessary to be aware of the fact that ethical decisions are predisposed by the pressure of the existence of individual factors, their significance and drawing attention to them the actors of the specific organisational environment, and - finally - they are determined by the nature of circumstances of their implementation. According to this model, the decision-making process is multidimensional and to a great extent process-oriented.

Individual traits and environmental conditions belong to the variables-determinant category, to which belong: individual background or socialisation characteristics such as education and professional know-how. When it comes to individuals, there are products of their values, attitudes and norms which they preach. They do not come from the organisation or

22 O. Mital, Ethics in Public Administration connected and the Application of Codes of Conduct, "Public Administration and Society" 2016, Vol. 17, Iss. 1, p. 56-66. 
the whole society as such but are predominantly the outcomes of various social groups, groupings and different societal backgrounds.

The environmental characteristics include influences exerted by external actors such as other organisations and clients as well as the organisation's internal influences embodied by its working groups and leadership.

Originally, the Ferrell and Gresham model was designed for the area of marketing but at the same time in their study they suggest the applicability of their model in other functional areas and organisations, and we can say that in fact they might cover the entire area of public integrity. The similarity lies in ethical problem areas as public servants might come into analogous contacts with similar situations as employees in business management or marketing decision processes focused on what is proper and ethical and what is improper and unethical to do in order to avoid such wrongs and injustices as conflict of interest, clientelism, nepotism, bribery or corruption.

Finally, we can say that the most important contribution of this model lies in its authors' interests in what role is played by the determinant variables, more precisely by the variable determinants in decision-making processes. Their main aim is the examination and assessment of the role of the context within which decisions are made. The authors refuse to support the idea of hypothetically created ethical dogmas and rules which would be without any exception valid for all solutions and for all individual cases. Another idea suggested by them is the attitude that ethical standards are in constant development. Additionally, they are interconnected and determined by a specific case and a specific situation and context.

\subsection{Dennis Wittmer's ethical decision-making model}

Dennis Wittmer's ethical decision-making model is of general nature, was elaborated in 1993 and popularised in 2005. It offers a useful framework for making decisions illustrating the recent progress of our understanding and comprehension how individual actors make decisions. It is the outcome of a synthesis of many previously postulated models of ethical decision-making, mainly those of Rest, Treviño and Thomas Jones.

The Wittmer model tries to incorporate different aspects of previously existing models, including sensitivity and perception of ethical issues, reasoning done to come to some conclusions regarding a specific case, influence of various individual and environmental factors having an important impact on decision-making processes implied at the public administration managerial level and in organisational work settings.

Rest's model creates the foundation for the understanding of ethical decision-making from the psychological perspective. According to his thinking, the decision-making process is of cognitive nature and consists of four components; interpretation of the situation, reasonable judgment, choice of alternative solutions and the finally resulting action. 
Another fundamental pillar of Wittmer's model of the ethical decision is that proposed by L. Treviño. It incorporates two essential features influencing decision-making; traits of individuals and environmental characteristics.

A synthesis of the aforementioned models shows that ethical decisionmaking is a combination conditioned by various aspects of the existing conceptual models including sensitivity to ethical questions.

As a result, Wittmer's model reflects both a cognitive process for resolving moral and ethical decisions, starting with awareness, perception and sensitivity to moral issues. The cognitive process continues by a moral judgment of the decision-maker and as a result of the final conclusion it is considered to be a well thought-out outcome of a hypothetically justified ethical course of reasoning finalised by the final choice of action and behaviour of the decision-maker. Wittmer's model shows that the process of ethical decision-making depends on various individual and environmental influences.

The table of Wittmer's model shows how and where individual factors enter into the decision-making process and influence it. Consequently, the ethical decision is dependent on individual and environmental factors which might enter into the process at any phase and thus influence the result of the decision, e.g. organisational culture requiring strict obedience to authority. Ethical decision-making is determined by individual characteristics, e.g. age, experience, etc. as well as by the environment, e.g. ethical climate in the organisation, dominance of punishment/award, the organisation's policies or code of conduct.

In his model, the cognitive processes takes centre stage while the noncognitive individual variables, e.g. ego strength, and the environmental factors, internal as well as external, e.g. ethical climate, social atmosphere, etc. encircle the inner centre stage exerting outside influences on decisionmaking processes.

Wittmer's general model of decision-making significantly influences public administration organisations by informing their executives that the ethical nature of their decisions concerning the public is many-sided and influenced by environmental factors, ethical organisational set-up and impacts exerted by the individual's sensitivity to ethical questions and problems. Summing up, we can describe Wittmer's general behavioural model of taking decisions as: Ethical decision-making $=f$ (ethical decision processes, individual attributes, Environmental factors). 
Figure 4. General Behavioural Model for ethical decision-making

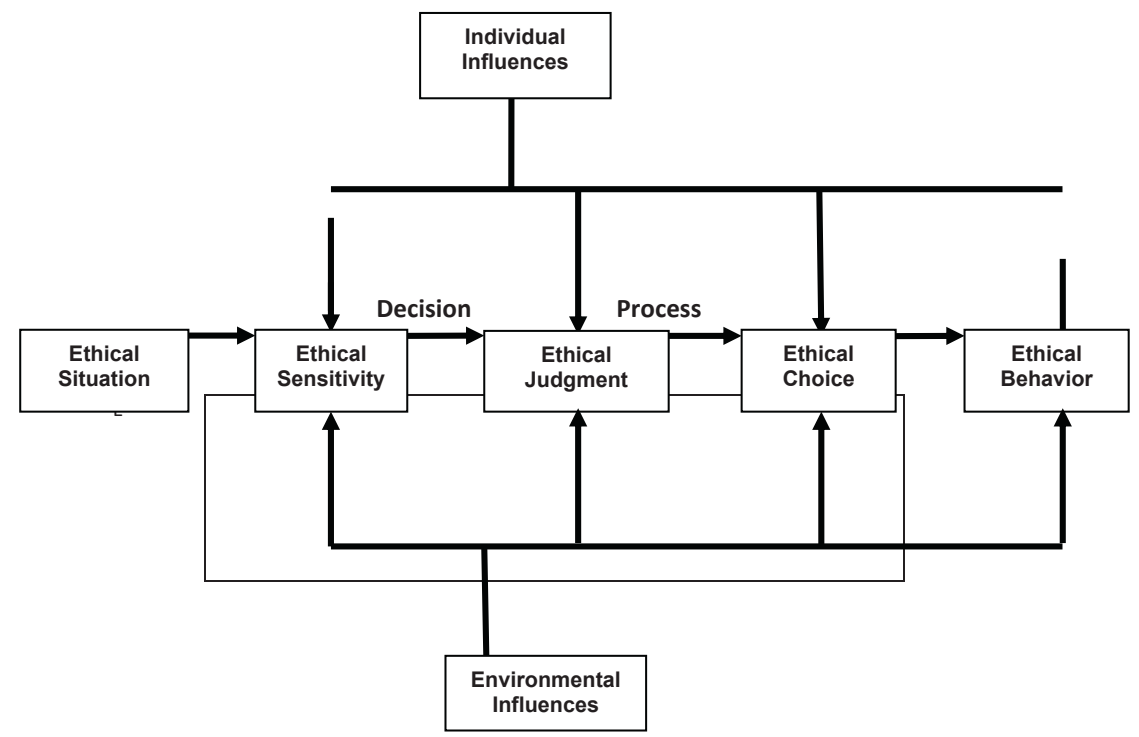

Source: D. Wittmer, p. 54, modified by the author.

\section{Conclusion}

The practical area of public administration lacks an integrated and systematic programme of ethics. It is scattered across many international documents and reflected by various European materials: we can say that they are only slowly reaching the stage of practice, and if they do, their implementation is entails many difficulties and obstacles.

In EU Member States, there is no unified system regarding ethical public administration which would be applicable at least in some areas of activities and decision-making processes. The EU countries define their public administration service systems differently, and at the same time they differ considerably regarding the political dominance of their public administration and the ethical attitude in public administrative bodies and organisations. On top of that, absent still is a kind of a unified European policy which would be specifically devoted to these problem areas. In spite of this, governments of individual states try to provide certain reforms in their public administration systems aimed at deeper Europeanisation, holding discussions concerning the European administrative space which might bring some common European administrative principles in the area of ethical action and decision-making.

Finally, we can come to the conclusion that in comparison to the Slovak Republic some countries pay greater attention to preserving ethical values 
and standards in their public administration activities and decision-making processes. This deficiency might be explained by the fact that Slovakia does not have an independent body which would be responsible for the implementation of ethics in public administration as is the case in some European and non-European countries, e. g. in Great Britain, such duties are fulfilled by the special Committee for the Ethical Standards in Public Life, in the USA the Office for Ethics in Public Administration has been established, while in Norway these tasks are fulfilled by the Ministry of State Service and Directorate-Management of the Public Administration.

In conclusion, we can mention the OECD basic recommendations which might be valid for states in order to improve their ethical environment in public administration bodies and organisations across levels. They are as following follows:

- the development and regular review of ethics policies and procedures,

- the promotion of government action to impose ethical standards,

- the incorporation of ethics into administrative reforms and management practices,

- the integration of procedural rules and ethical values ${ }^{23}$.

\section{Bibliography}

Bommer M. et al., A behavioural model of ethical and unethical decision-making, "Journal of Business Ethics" 1987, Vol. 6, No. 4.

Bovaird T., Löffer E., Public Management and Governance, New York: Routledge 2013.

Council of Europe, The Ethical Leadership Program: A Facilitator's Guide 2009, Council of Europe Project No. EC/1062, http://www.coe.int/t/DGHL/cooperation/economiccrime/corruption/projects/TYEC/1062-TYEC-Facilitators\%20 Guide.pdf.

Diamandouros P.N., European Ombudsman speech on Open dialogue between institutions and citizens - the way forward, 2012, www.ombudsman.europa.eu/en/ activities/.../en/.../html.bookmar.

Džatková V., E-participation in the public administration modernization processes [in:] Actual Challenges and Problems of Public Administration II, Košice: Faculty of Public Administration UPJŠ in Kosice 2015.

European Governance: A White Paper, Commission of the European Communities, $\operatorname{COM}(2001)$.

Európsky ombudsman, Zásady verejnej služby pre verejno službu EÚ 2012, http:// www.ombudsman.europa.eu/sk/resources/ publicserviceprinciples.faces.

Ferrell O.C., Gresham L.G., A contingency framework for understanding ethical decision making in marketing, "Journal of Marketing" 1985, Vol. 49, No. 3.

23 OECD, Principles for Managing Ethics in the Public Service, Paris, http://www. oecd.org/dataoecd/60/13/1899138.pdf, 22 December 2004. 
Garofalo Ch., Governance and Values in Contemporary Public Service [in:] Value and Virtue in public Administration, a Comparative Perspective, M.S. De Vries, P. Kim (eds.), United Kingdom: Palgrave MacMillan 2014.

Haque M.S., Contemporary Trends and Dilemmas of Administrative Ethics in the Developing World [in:] Value and Virtue in public Administration, a Comparative Perspective, M.S. De Vries, P. Kim (eds.), United Kingdom: Palgrave MacMillan 2014.

Heywood A., Global politics 2, UK: Palgrave Macmillan 2014.

Hondeghem A., Ethics and accountability in a context of governance and new public management, Amsterdam: IOS Press 1998.

Jensen L.S., Kennedy S.S., Public Ethics, Legal Accountability, and the New Governance [in:] Ethics in Public Management, H.G Frederickson, R.K. Ghere (eds.), New York: M.E. Sharp, Inc. 2005.

Johnson C.E., Meeting the Ethical Challenges of Leadership, Casting Light or Shadow, California: SAGE Publications, Inc. 2009.

Jurkiewicz C.L., Power and Ethics: The Communal language of Effective Leadership [in:] Ethics in Public Management. Collection of papers, New York: M.E. Sharpe, Inc. 2005.

Mital' O., Ethics in Public Administration and Ethical Codes of Conduct, "Public Administration and Society" 2016, Vol. 17, Iss. 1.

OECD, Building Public Trust: Ethics Measures in OECD Countries, PUMA Policy Brief No. 7, 2000, Paris.

OECD, Principles for Managing Ethics in the Public Service, Paris, http://www.oecd. org/dataoecd/60/13/1899138.pdf, 22 December 2004.

Public consultation on the draft statement of public service principles for EU civil servants, 24 February 2011.

Rosenbloom D.H., Public Administration, Understanding Management, Politics, and Law in the Public Sector, New York: Random House 1986.

Svara J., Ethics Primer for Public Administrators in Government and Non-profit Organizations, Sudbury: Jones and Bartlett Publishers 2007.

Treviño L., Ethical Decision Making in Organizations: A Person-Situation Interactionist Model, "Academy of Management Review" 1986, No. 1.

Treviño L., Nelson K., Managing Business Ethics; straight talk about how to do it right, John Wiley and Sons 2010.

Verejná etika na miestnej úrovni, súbor modelových iniciatív, dokument Rady Európy vydaný v spolupráci s Ministerstvom vnútra Slovenskej republiky, Bratislava: PPA.

Vigoda E., From Responsiveness to Collaboration: Governance, Citizens, and the Next Generation of public Administration, "Public Administration Review", September/October, 2002, Vol. 62, No. 5.

Abstract

The question of ethics is one closely linked to human existence involving character traits, conduct, ethics and morals of human beings. As, first and foremost, ethics has to do with actions of man, it requires adjustments in one's actions and attitudes, especially in the case of public administration, its management activities, decision-making 
processes, leadership and administrators in relation not only to their colleagues and superiors but the citizenry and general public having in mind the basic principle of democracy and its main attribute that is public participation in governing public affairs. The paper consists of several parts dealing with aspects of traditional and modern democratic public administration in relation to the active participation of citizens, ethical public management and leadership connected with the ethical decision-making processes, ethical models of decisions and their conceivable application in public administration.

Keywords: public administration, traditional, modern, ethics, decision-making, models

\section{Wyzwania stojące przed nowoczesną administracją publiczną a podejmowanie decyzji z poszanowaniem zasad etyki \\ Streszczenie}

Kwestia etyki jest ściśle związana z ludzkim bytem, który obejmuje cechy charakteru, zachowanie oraz ludzką etykę i moralność. Ponieważ z zasady dotyczy zachowań ludzkich, wymaga dostosowania w zakresie działań i podejścia, zwłaszcza w przypadku administracji publicznej, jej obowiązków zarządczych, procesów decyzyjnych, przywództwa i administratorów. Podejmowanie decyzji z poszanowaniem zasad etyki obejmuje nie tylko kolegów i szefów, lecz również obywateli i opinię publiczną ze względu na podstawową zasadę demokracji i jej główny atrybut, czyli udział społeczeństwa w zarządzaniu sprawami publicznymi.

Artykuł podzielono na kilka części dotyczących różnych aspektów administracji w demokracji tradycyjnej i nowoczesnej w kontekście aktywnego uczestnictwa obywateli, etycznego zarządzania publicznego oraz przywództwa związanego z etycznymi procesami decyzyjnymi, etycznymi modelami decyzji, jak również ich możliwym zastosowaniem $\mathrm{w}$ administracji publicznej.

Słowa kluczowe: administracja publiczna, tradycyjny, nowoczesny, etyka, podejmowanie decyzji, modele 